\title{
Rapid electrophoresis and quantitation of haemoglobins on cellulose acetate
}

\author{
A. J. MARENGO-ROWE \\ From the Department of Research Biochemistry, Royal Air Force Institute of \\ Pathology and Tropical Medicine, Halton, Bucks
}

SYNOPSIS A rapid and reproducible electrophoretic method for the separation and quantitation of haemoglobins on cellulose acetate is described. The accuracy of the method and its possible sources of error are discussed. The normal range for haemoglobin $\mathrm{A}_{2}$ by this method is $1 \%$ to $3 \%$ of the $\mathscr{8}$ total haemoglobin concentration. Blood samples from 32 thalassaemic patients showed haemoglobin $A_{2}$ values of $3.5 \%$ to $7 \%$.

Filter paper and starch techniques for the separation and estimation of haemoglobins are prolonged and exacting and have not been readily adopted by clinical laboratories. Simpler methods employing cellulose acetate membrane as the supporting medium were suggested by Kohn (1958 and 1960) and developed by other authors (Petrakis, Doherty, Grunbaum, and Atchley, 1962; Friedman, 1962; Afonso, 1962; Graham and Grunbaum, 1963). These have disadvantages, such as the requirement for special apparatus and staining procedures, or a failure to quantitate the $A_{2}$ fraction. Bartlett (1963) obtained reproducible values for haemoglobin $\mathbf{A}_{2}$ in a small series of normal persons by eluting this fraction unstained.

The following method has been used in this laboratory under routine conditions and has given satisfactory and reproducible results; it is technically simple, requires no staining, and employs apparatus available in most laboratories. Results can be obtained within 90 minutes of receiving a blood sample.

\section{APPARATUS AND REAGENTS}

The apparatus requires a power pack capable of supplying direct current up to $10 \mathrm{~mA}$ at 200 volts, a tank suitable for electrophoresis on cellulose acetate in the horizontal plane, ${ }^{1}$ cellulose acetate strips $5 \times 12 \mathrm{~cm} .{ }^{2}$ and a spectrophotometer with a narrow wavelength band at $413 \mathrm{~m} \mu$; the Unicam SP 600 or the Hilger ultra-violet spectrophotometer are suitable instruments.

'Shandon Scientific Company Ltd., 65 Pound Lane, Willesden, N.W. 10.

${ }^{2}$ The Oxoid Division, Oxo Ltd., Southwark Bridge Road, S.E.1.

Received for publication 27 May 1965.
Tris buffer, $p \mathrm{H} 8 \cdot 9$, consists of Tris-(hydroxy-methyl)- $\frac{}{3}$ amino-methane, $14.5 \mathrm{~g} . / 1$. $(0 \cdot 12 \mathrm{M})$, ethylene-diamine- $\mathbb{\Phi}$ tetra-acetic acid, $1.5 \mathrm{~g} . / \mathrm{l}$. (0.005M), and boric acid, $0.9 \mathrm{~g} . / 1 .(0.015 \mathrm{M})$.

\section{PROCEDURE}

Blood, $2 \mathrm{ml}$, is taken into a heparinized bottle. Haemolysates are prepared by the method of Lehmann and Ager (1961). Conversion of oxyhaemoglobin to carboxyhaemoglobin is unnecessary if the solution is tested within three days.

The cellulose acetate strips are immersed in the Tris buffer for five minutes, blotted evenly between two sheets of Whatman no. 3 filter paper to remove excess moisture, and mounted horizontally in the electrophoretic tank. The strips are allowed to equilibrate in the closed unit for 10 minutes.

The qualitative separation of haemoglobins is performed on 1-2 $\mu \mathrm{l}$. samples of the haemolysate. The test samples and controls are applied as 1 to $1.5 \mathrm{~cm}$. bands and placed $0.5 \mathrm{~cm}$. on the cathode side of the mid point $\frac{\mathrm{O}}{5}$ of the strip. Several specimens may be run simultaneously. Optimal separation occurs in 45 minutes at 20 to 25 O volts $/ \mathrm{cm}$. with a current of 0.3 to $0.5 \mathrm{~mA} / \mathrm{cm}$. The quantitation of the haemoglobins is performed in a $\mathcal{N}$ similar manner to the qualitative procedure with the $N$ exception that approximately $30 \mu \mathrm{l}$. of the haemolysate $\stackrel{\sim}{\mathcal{N}}$ is applied as three $5 \mu$ l. samples to each of two cellulose $\omega$ acetate strips. The strips are removed after a 45-minute period of electrophoresis and cut midway between the 0 areas of greatest concentration. The haemoglobin fractions $\frac{C}{\Phi}$ to be quantitated, other than $A_{2}$, are placed in a plastic- $\stackrel{?}{?}$ capped test tube and eluted in $20 \mathrm{ml}$. of Tris buffer by rotation on a blood-mixer for $\mathbf{3 0}$ minutes. It is necessary to elute the $A_{2}$ fractions in $4 \mathrm{ml}$. of buffer because of the $\vec{D}$ smaller quantities involved. This approximates the $\frac{?}{\mathbb{D}}$ intensities of the solutions to be compared. The eluates $\stackrel{\mathbb{Q}}{\Omega}$ are measured in a spectrophotometer at a wavelength of $\bar{Q}$ 


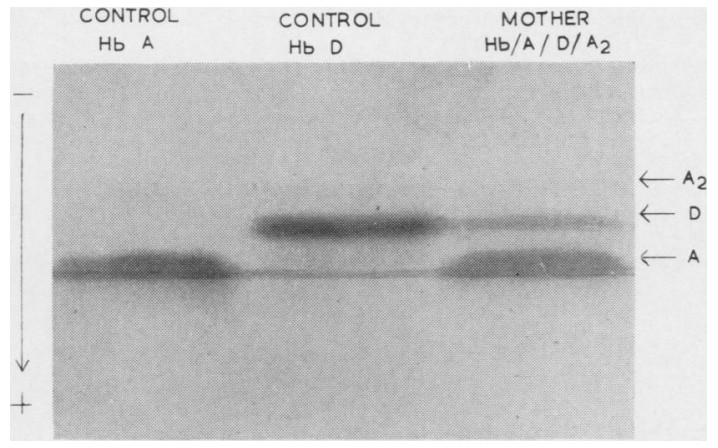

FIG. 1. Qualitative separation of haemoglobins $A, D$, and $A_{2}$.

$413 \mathrm{~m} \mu$ and percentages calculated. Maximum absorption for oxyhaemoglobin solutions of $\mathrm{A}, \mathrm{A}_{2}, \mathrm{D}, \mathrm{S}, \mathrm{C}$, and $\mathrm{H}$ is recorded at this wavelength.

\section{RESULTS AND DISCUSSION}

The site of application of the haemolysate to the cellulose acetate strip is critical. At the point selected the migrating tendency of haemoglobin A towards the anode is balanced by the endosmotic flow of buffer towards the cathode. Haemoglobin A remains stationary whereas haemoglobins such as $\mathrm{D}$ and $\mathrm{A}_{2}$ are carried endosmotically towards the cathode (Fig. 1). Thus haemoglobin $\mathrm{A}$ is prevented from migrating through the final locations of the other haemoglobins. This factor, coupled with the excellent resolving properties of cellulose acetate, gives rise to sharp zones of separation. Good results are obtained with haemoglobins A, C, D, H, S, and $A_{2}$. Additional analytical procedures are required for the differentiation of haemoglobins with similar electrophoretic mobilities at $p \mathrm{H} \mathrm{8.9,} \mathrm{such} \mathrm{as} \mathrm{E}$ and $\mathrm{A}_{2}$ or $\mathrm{S}$ and $\mathrm{D}$.

The range of normal values for haemoglobin $A_{2}$ for 67 healthy adults between the ages of 18 and 52 is $1 \%$ to $3 \%$ of the total haemoglobin concentration. The mean percentage is 2.0 with a standard deviation of \pm 0.51 . The mean percentage of haemoglobin $A_{2}$ is slightly lower than that reported in previous studies (Table). The disparity may be attributed to incomplete separation of haemoglobin $\mathrm{A}$ and $\mathrm{A}_{2}$ by filter paper techniques because of trailing of the more rapidly migrating $A$ fraction. In addition, the quantitative relationship between the haemoglobin concentration and uptake of stain is linear only between certain narrow ranges (Graham and Grunbaum, 1963), and their relation to the area under the optical density curve may deviate from the Beer-Lambert law when direct photometry is employed.

The reproducibility of the method was tested by 21 replicate measurements of haemoglobin $\mathrm{A}_{2}$ on a normal sample. The results showed a mean value of $1.5 \%$ with a standard deviation of $\pm 0 \cdot 14$. Potential sources of error arise from inaccurate cutting out of the haemoglobin bands and incomplete elution.

Blood samples from 32 patients with heterozygous thalassaemia which were examined by this method showed haemoglobin $A_{2}$ values of $3.5 \%$ to $7 \%$ (Fig. 2).

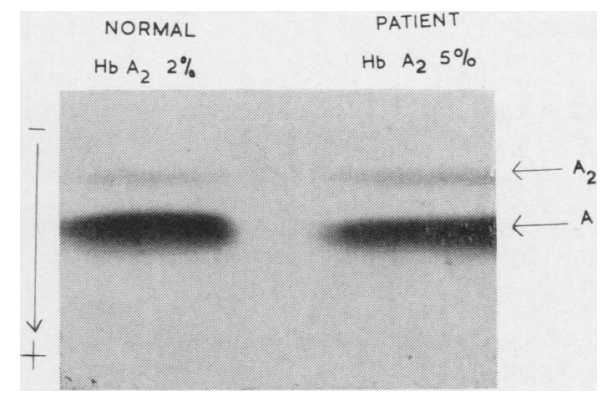

FIG. 2. Electrophoretic patterns obtained from the blood of normal and thalassaemic persons.

My thanks are due to Air Commodore W. P. Stamm, Dr. H. Bowden and Squadron Leader A. W. McCracken for encouragement and advice, to Mr. J. Watkin for

TABLE

PERCENTAGE OF HAEMOGLOBIN A A $_{2}$ IN NORMAL PERSONS

\begin{tabular}{|c|c|c|c|c|c|}
\hline Authors & Date & Technique & No. & Mean & $\%$ Range \\
\hline $\begin{array}{l}\text { Kunkel and Wallenius } \\
\text { Masri, Josephson, and Singer } \\
\text { Gerald and Diamond } \\
\text { Ibbotson and Crompton } \\
\text { Hilgartner, Erlandson, Walden, and Smith } \\
\text { Afonso } \\
\text { Petrakis et al. } \\
\text { Bartlett } \\
\text { Graham and Grunbaum } \\
\text { Present investigation }\end{array}$ & $\begin{array}{l}1955 \\
1958 \\
1958 \\
1961 \\
1961 \\
1962 \\
1962 \\
1963 \\
1963 \\
1965\end{array}$ & $\begin{array}{l}\text { Starch block } \\
\text { Starch block } \\
\text { Starch block } \\
\text { Filter paper } \\
\text { Filter paper } \\
\text { Cellulose acetate } \\
\text { Cellulose acetate } \\
\text { Cellulose acetate } \\
\text { Cellulose acetate } \\
\text { Cellulose acetate }\end{array}$ & $\begin{array}{r}26 \\
230 \\
20 \\
86 \\
22 \\
40 \\
28 \\
17 \\
64 \\
67\end{array}$ & $\begin{array}{l}2 \cdot 6 \\
2 \cdot 6 \\
2 \cdot 4 \\
3 \cdot 2 \\
9 \cdot 9 \\
2 \cdot 6 \\
3 \cdot 5 \\
2 \cdot 5 \\
2 \cdot 8 \\
2 \cdot 0\end{array}$ & $\begin{array}{l}1.8 \text { to } 3.5 \\
1.2 \text { to } 3.5 \\
1.7 \text { to } 3.1 \\
1.4 \text { to } 4.3 \\
5.0 \text { to } 14.3 \\
1.4 \text { to } 3.8 \\
1.5 \text { to } 6.1 \\
1.8 \text { to } 3.2 \\
1.1 \text { to } 4.5 \\
1.0 \text { to } 3.0\end{array}$ \\
\hline
\end{tabular}


photography, and to the Director-General of Medical Services, Royal Air Force, for permission to publish.

\section{REFERENCES}

Afonso, E. (1962). Clin. Chim. Acta, 7, 545.

Bartlett, R. C. (1963). Clin. Chem., 9, 325.

Friedman, H. S. (1962). Clin. Chim. Acta, 7, 100

Gerald, P. S., and Diamond, L. K. (1958). Blood, 13, 61 .

Graham, J. L., and Grunbaum, B. W. (1963). Amer. J. clin. Path., 39, 567.
Hilgartner, M. W., Erlandson, M. E., Walden, B. S., and Smith, C. H. (1961). Ibid., 35, 26.

Ibbotson, R. N., and Crompton, B. A. (1961). J. clin. Path., 14, 164.

Kohn, J. (1958). Trans. roy. Soc. trop. Med. Hyg., 52, 304.

- (1960). In Chromatographic and Electrophoretic Techniques, edited by I. Smith, vol. 2, Zone Electrophoresis, pp. 56-90. Heinemann, London.

Kunkel, H. G., and Wallenius, G. (1955). Science, 122, 288.

Lehmann, H., and Ager, J. A. M. (1961). A.C.P. Broadsheets, No. 33.

Masri, M. S., Josephson, A. M., and Singer, K. (1958). Blood, 13, 533. ఝ

Petrakis, N. L., Doherty, M. A., Grunbaum, B. W., and Atchley, W. A. (1962). Acta haemat. (Basel), 27, 96.

\section{The September 1965 Issue}

\section{THE SEPTEMBER 1965 ISSUE CONTAINS THE FOLLOWING PAPERS}

Platelet fibrinogen P. A. CASTALDI and J. CAEN

Localization of plasminogen activator in neonatal lung in the presence of hyaline membrane disease J. T. ROBERTS

Necrotizing arteritis with giant cells associated with haemolytic anaemia P. FLANAGAN, A. W. MCCRACKEN, F. R. JONES, and R. M. CROSS

Reversible absorptive defects in anticonvulsant megaloblastic anaemia E. H. REYNOLDS, J. F. HALLPIKE, B. M. PHILLIPS, and D. M. MATTHEWS

Enzymatic release of folate activity from the red cells in megaloblastic anaemia of pregnancy HELENA GRZESIUKOWICZ, R. F. JENNISON, and A. H. GOWENLOCK

Detection by paper chromatography of imidazoles, including hydantoin-5-propionic acid, in urine after histidine dosage J. E. MIDDLETON

Simultaneous free and bound radioactive vitamin $\mathbf{B}_{12}$ urinary excretion test T. K. BELL, J. M. BRIDGES, and M. G. NELSON

Two fatal cases of septicaemia due to Erysipelothrix insidiosa CHRISTOPHER A. MORRIS, HERTA SCHWABACHER, PATRICK G. LYNCH, CLARA D. CROSS, and TITUS O. DADA

A bacteriological study of non-chromogenic variants of Serratia marcescens from human sources H. R. ELSTON

Neutral and visceral xanthomatosis in adults A. A. MILLER and F. RAMSDEN

Cerebral infarction due to intracranial sinus thrombosis M. ATA

Lipid studies in the blood and brain in multiple sclerosis and motor neurone disease J. N. CUMMINGS, R. C. SHORTMAN, and T. SKRBIC

Systemic idiopathic fibrosis and systemic WeberChristian disease M. J. MITCHINSON
Malignant change and multiple metastases in Ollier's disease $W$. K. COWAN

Gel immunofiltration. A new technique for the qualitative analysis of serum proteins G. H. GRANT and P. H. EVERALL

Serum enzymes in diseases of the thyroid gland P. D. GRIFFIFTHS

Electrophoretic behaviour of human urinary amylase C. FRANZINI

Release of formaldehyde from polynoxylin and noxythiolin D. KINGSTON

Serial laboratory reports and records for chemical analyses L. G. WHITBY and J. A. OWEN

Cumulative reporting of chemical pathology F. v. $\overline{\overline{3}}$ FLYNN and JILL VERNON

\section{Technical methods}

Estimation of sodium, potassium and chloride in urine using a Technicon AutoAnalyzer J. K. DAWBORN, C. PATALINGHUG, and S. E. L. BLACK

Estimation of hydroxyproline by the AutoAnalyzer R. A. GRANT

An ortho-tolidine hydrochloride test for the detection of $\frac{\text { O }}{2}$ occult blood in faeces without dietary restrictions NAGI $D$ WAHBA

Break-off capillary tube method for blood counts $\mathbb{N}$ S. M. LEWIS and H. BENJAMIN

A simple microscope attachment for making multiple width measurements of long fibres E. A. WRIGHT

Book reviews

Certificate and Diploma in mortuary hygiene and $\stackrel{\mathscr{C}}{\rightarrow}$ technology for post-mortem room technicians J. F. HEGGIE

Copies are still available and may be obtained from the PUBLISHING MANAGER, BRITISH MEDICAL ASSOCIATION, TAVISTOCK SQUARE, W.C.I., price 18s. 6D. 